Revista do CESP, Belo Horizonte, v.34, n.52, p. 163-180, 2014

\title{
Agustina Bessa-Luís entre mitos brasileiros
}

\section{Agustina Bessa-Luis among brazilian myths}

\author{
Odalice de Castro Silva \\ Universidade Federal do Ceará (UFC), Fortaleza, Ceará, Brasil \\ ocastroesilva@gmail.com
}

Resumo: Este trabalho propõe uma discussão acerca das migrações de escritores, de travessias e de deslocamentos entre Portugal e Brasil, em especial na formação e na trajetória literária e intelectual de Agustina Bessa-Luís (1922-), tomando, por base de reflexão, categorias como cânone, por Harold Bloom (1991), paratopia, segundo Dominique Maingueneau (2005), errância, para Mauro Maldonato (2004), e os fundamentos da nova historiografia literária, por José Luis Jobim, como tradição e origem (1994). A proposta de reflexão será desenvolvida a partir do discurso que a escritora portuguesa proferiu em 1989, no Rio de Janeiro, na Academia Brasileira de Letras, como parte de seus compromissos, juntamente com outros intelectuais, da viagem que compreendeu vários estados brasileiros, conforme está registrado em Breviário do Brasil (1991), escrito após seu retorno a Portugal.

Palavras-chave: Trânsitos culturais; escritura; mito; memória

Abstract: This paper proposes a discussion about migration of writers, crossings and displacements between Portugal and Brazil, particularly in the education and literary and intellectual history of Agustina Bessa-Luís (1992-), based on reflection, categories such as canon by Harold Bloom (1991), paratopia according to Maingueneau Dominique (2005), errância to Mauro Maldonato (2004), and the foundations of new literary historiography, by José Luis Jobim, as tradition and origin (1994). The proposed reflection will be developed from the speech that the portuguese writer gave in 1989, in Rio de Janeiro, in the Academia Brasileira de Letras, as part of its commitments, along with other intellectuals, the journey which comprised several brazilian states, as it is recorded in Breviário do Brasil (1991), written after her return to Portugal.

Keywords: Cultural influences; writing; myth; memory 
Recebido em 26 de maio de 2014. Aprovado em 30 de agosto de 2014.

Eu não queria o êxito fácil, as opiniões, os favores, os agasalhos da tertúlia e o calor da insubordinação, dos injustiçados, dos paladinos da razão. Eu só queria escrever, entrar no coração das pessoas e beber-lhes o sangue, avançando sempre, criando enredos e fazendo saltar os personagens das páginas. Há pouca gente que perceba que escrever é uma espécie de danação em que às vezes se têm encontros com Deus. Eu perguntava: lutar com o Anjo, o que significa Jacob lutou com o Anjo e ficou aleijado para sempre. Esse aleijão é a pessoa que tem uma ideia sobre a sua existência na terra e lhe dá forma pelas palavras, rios de palavras, rios de incerteza profunda.

Agustina Bessa-Luís

- Eu cultivo cactos como se fossem rosas. A beleza deles, que pode ser vista uma só vez na vida, não se compara a nada. É como uma aparição.

Agustina Bessa-Luís

No Brasil, onde muitas mudanças se operam, eu notei no homem comum um respeito profundo pela bondade que, de certo modo, não se adopta ou se cultiva como identidade coletiva, mas que não está condenada.

Agustina Bessa-Luís

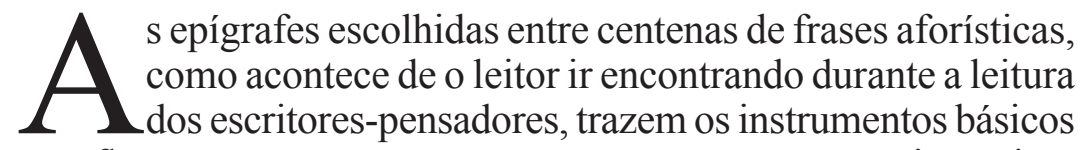
para uma reflexão como a que propusemos para este exercício crítico: um plano, as metas, as estratégias, um método.

As três epígrafes pertencem a textos de uma mesma época, entre 2001 e 2003, da trajetória de escrita de Agustina Bessa-Luís (1922-). O Livro de Agustina Bessa-Luís e A alma dos ricos, o segundo livro da trilogia $O$ princípio da incerteza, contribuem com régua, prumo 
e compasso, para que sejam expostas as linhas gerais de uma rápida passagem-desafio de analisar e interpretar os motivos desta proposta.

O plano consciente de escrita, como se pode constatar desde Mundo fechado (1948), antecedido de dois livros não publicados, Ídolo de barro e Água da contradição, datilografados a mando de seu pai, já maturava a decisão de se descobrir escritora: (Ídolo de barro) "Escrevi-o no Douro, em tempo de exílio e de prostração. Não direi de depressão, porque não chegou a tanto. Eu tinha quinze anos e a família decidiu voltar à província, atravessando uma crise financeira, a primeira de que tinha conhecimento".'

No mesmo ano de 1948, são lançadas as densas e polêmicas interrogações que desenvolvem os três primeiros capítulos de $O$ que é literatura, por Jean-Paul Sartre, como consequência de uma intelectualidade que se perguntava acerca dos motivos da escrita literária depois das duas guerras que devastaram expectativas e projetos e encerraram em definitivo um século que demorava em concluir um tempo de promessas e enganos, tendo por pano de fundo os paradoxos do progresso e das tecnologias que afastavam, de forma célere, as últimas ilusões da solidez e das certezas, embora estas já se dissolvessem desde meados do século XIX, quando a Europa Ocidental se transformava através de um outro paradigma civilizacional: o da queda dos impérios.

São interessantes as aproximações ideológicas entre a base que sustenta as discussões e as relações internas de Mundo fechado e as perguntas de $O$ que é literatura, fortalecidas pelos vínculos que alimentaram a obra dos dois escritores, Agustina e Sartre, a ficção e o pensamento, a reflexão e a metáfora.

Os primeiros livros provocaram reações da crítica literária e, a partir dos desafios da escrita de Agustina, aos poucos, teve início um processo que dura até os dias de hoje: a literatura - dentro de um campo de forças - luta pelo espaço em que circulam quem escreve, quem lê, o que se escreve, através de que meios.

Neste campo de forças, em que se cruzam "ideologias", para usar o termo de Roland Barthes, como sinônimo de "filosofias", Agustina experimenta a escrita que não prometia meias palavras, que não se comprometia com os projetos já consagrados e pertencentes já a outros tempos, aqueles que já haviam cumprido, ou não, o que haviam se proposto para o seu tempo.

${ }^{1}$ BESSA-LUÍS, 2007, p. 59. 
Como uma anarquista, a um tempo, rebelde e serena, Agustina, já conhecida como autora do romance premiado, A Sibila, em 1954, reforça uma conjugação complexa que será a sua marca, com a qual sinalizava a diferença de sua escrita de uma postura:

É curioso notar quanto o espírito prático, o senso da justa
medida está na razão contrária da obra de arte. Em Portugal,
existe essa noção do correcto, do inteligente, do equilibrado,
escreve-se uma prosa que é a própria burocracia do
sentimento, as pessoas exprimem-se, apresentam-se, usam-
se, com essa obstinação de princípios que proporciona bons
chefes de família e intelectuais falhados. ${ }^{2}$

A percepção da Arte na contramão do espírito prático, através das imagens derivadas de um racionalismo insuficiente para as dimensões das representações da vida, caracteriza bem uma compreensão de que as linguagens da Vida e as linguagens da Arte não cabem na burocratização e nos organogramas com que são compartimentados o inesperado, as surpresas, as errâncias, as falhas, os despropósitos.

A percepção deceptiva da Vida e da Arte não cabe em corredores estreitos. Tais fórmulas podem até convencer os incautos, podem vir a engendrar "bons chefes de família e intelectuais falhados", mas nunca os que provaram a face prismática da Vida e da Arte. As duas só cabem na visão complexa do infinito, feito de movimentos incertos e errantes.

O crítico Óscar Lopes, ao analisar Contos impopulares, de 1952, alcançara essa percepção em relação ao traçado da arte de Agustina e com as palavras dele, uma síntese que se aprofundaria com a construção de sua obra, feita de vários gêneros e formas: "É curioso como uma tão fina e nervosa notação do real parece varrida por um vento de sobrenaturalidade". ${ }^{3}$ Estavam definidas as linhas da obra de Agustina: a realidade da vida e as dimensões de seu mistério.

Deste modo, este exercício também já pode traçar seus caminhos, adotando categorias que orientarão o plano destas reflexões: complexidade, errância, travessia, paratopia e os companheiros de toda uma vida - os escritores, os poetas, os pensadores, os profetas queridos, os livros de cabeceira, com os quais traçou seus próprios caminhos.

\footnotetext{
${ }^{2}$ BESSA-LUÍS apud Machado, 1979, p. 17.

${ }^{3}$ LOPES apud Machado, 1979, p. 16.
} 
Agustina adota a errância, um modo de ser no mundo, de acordo com a escolha de ser mulher-escritor: o cosmopolitismo do viajante nômade; uma forma de praticar a paratopia, o deslocamento estudado por Dominique Maingueneau a partir das lutas e disputas de quem escreve e tenta fazer com que sua voz se destaque no tumulto de vozes que se alteiam e, às vezes, se altercam no que bem se denomina de campo literário, na categoria cunhada por Pierre Bourdieu. ${ }^{4}$

Do Porto para itinerários desenhados por tantos países da Europa e por outros continentes, Agustina, em 1979, analisa os primeiros trinta anos de uma vida literária, entre os momentos de escrita e as viagens, levando consigo as experiências e a responsabilidade com a forma que reinventava:

$\mathrm{O}$ escritor, desde os seus começos, tem que obedecer a uma ideia, que é a mesma pela vida fora. Não se desvia dela um passo; ela tiraniza-o, e obriga-o a tentar sempre a arte de a exprimir, cada vez mais calibrada pela sua própria consciência e mais instituída no seu estilo. Por isso, trinta anos de vida literária são um só dia. E um dia de trabalho é igual à eternidade das nossas tentativas para o mundo especial de todos os tempos. ${ }^{5}$

A fidelidade a uma ideia, uma percepção abissal do tempo, o movimento de grandes rosáceas para figurar a fragmentação dos sentidos do ser são a constatação humilde com que acolhe as homenagens, pelas três primeiras décadas, que lhe foram dedicadas pelos meios de comunicação. Espraiava-se, em ondas, a voz que começara em 1948, abrindo um mundo de símbolos: "Da noite, da sombra que caía em círculo sobre o vale, da expressão hermética das coisas e das criaturas, expandia-se o estranho sortilégio dum belo mundo fechado." 6

Nos vinte e cinco livros escritos durante as três primeiras décadas, a luz que incide sobre os recantos e os ângulos não alcançados pelo olhar que esquadrinha as cenas das narrativas, pesadas pelo drama da humanização do homem, também acentua a força da sombra que resguarda os conflitos íntimos, os comportamentos sem explicação, os crimes insondáveis, os gritos que vêm de outras eras, as paixões sem amanhã. Os

\footnotetext{
${ }^{4}$ BOURDIEU, 1996.

${ }^{5}$ BESSA-LUÍS apud Machado, 1979, p. 20.

${ }^{6}$ BESSA-LUÍS, 1948, p. 6.
} 
temas da humanização do homem vão buscar os tempos arcaicos, quando os movimentos no espaço eram contados com a medida da eternidade.

A percepção complexa da errância teria começado na imagem dupla do pai, o que saiu de Portugal ainda criança, fez-se ao mundo e voltou do Brasil como brasileiro, das terras da Bahia para as do Rio de Janeiro, onde cresceu e enriqueceu, vivendo uma vocação da aventura: "Entrou no submundo do Rio, vivia na praia como outros da mesma idade a comer o peixe deixado pelos pescadores. Fez-se corredor num rink de patinagem. Entrou no jogo com um mulato que, possivelmente, era o banqueiro e o lado facinoroso da sociedade. O jogo era um campo de acesso à fortuna e às relações perigosas." ${ }^{7}$

$\mathrm{E}$, sobre o tempo do enriquecimento no Brasil descem pesadas sombras; a estas Agustina emprestará a força da ficção, a fim de, sob o manto da fantasia e da imaginação, criar enredos para personagens com espaços lacunosos, de suspeitas sem solução. É de dentro das pesadas sombras que Agustina vai dando forma a rostos, a falas, a desejos, a perdas, a frustrações, a mistérios, a desenhos do que chamamos o Outro.

São divagações necessárias à percepção do mundo de Agustina, necessárias como uma senha para entrar no silêncio de uma escrita que se dilacera no incansável questionamento de sua razão de ser, como um viajante avançando por sílabas, palavras, frases, orações, períodos, sempre longos, complexos, labirínticos, traçados com sinais barrocos, laboriosamente encadeados para ouvir as falas que brotam do coração das trevas:

No deserto, onde o silêncio se alimenta de seus próprios ecos, das ressonâncias reunidas no coração da ausência, nenhuma morada pode ser medida pelo fundamento, mas pela inapreensível errância do pensamento. Aqui, onde toda migração acontece, toda identidade se dispersa, todo signo nada mais é que signo, e a palavra é um eco para além do mundo, um movimento que traça o sentido exato e inalcançável de um horizonte, que transforma figuras impossíveis em visões. ${ }^{8}$

As imagens criadas por Mauro Maldonato, animadas pelo campo semântico do desejo de escuta, nascem da percepção complexa, princípio

\footnotetext{
${ }^{7}$ BESSA-LUÍS, 2007, p. 6.

${ }^{8}$ MALDONATO, 2004, p. 32.
} 
com que dialogam o pensamento de Mauro Maldonato e o de Edgar Morin, pensadores que experimentaram, "entre vida e pensamento, uma conversão recíproca", ${ }^{9}$ uma "subversão criadora", a partir de uma compreensão em que categorias como "sujeito e objeto" perdem o caráter individual e unitário, para serem lançados em "sua trama múltipla e contraditória". ${ }^{10}$

Portanto, numa outra percepção epistemológica, cujos ecos ressoam nas ondas que abrem e encadeiam os fios das frases e dos períodos da escrita de Agustina, damo-nos a oportunidade de ler e interpretar suas figuras, nestas chaves nuançadas pela complexidade, pela errância, pelas fronteiras que se desmancham, mas que se elevam no obstáculo transparente das trocas, do torna-viagem, como na percepção de Jean Starobinski, quando o pensador interpretou a relação vidapensamento em Jean-Jacques Rousseau (1712-1778).

Encontrar a verdade, entre o pensamento, a arte e a vida. No curso da leitura de Agustina, a figura de seu pai estampa o mistério do Brasil:

Meu pai já tinha morrido quando eu fui pela primeira vez ao Brasil. Tudo indicava que não tinha deixado lá só amigos. Ele tivera um "habeas corpus" da polícia do Rio, era um elemento conciliador entre bandos. Acredito que fosse um homem temível e cujo estado recreativo é parecer o contrário. Imediatamente amei o Brasil, tanto na sua perigosidade, como na sua cultura que não é agressiva como a europeia. [...] Nada se compara à beleza do Brasil, a sua associação de flutuações da alma vegetal e animal. ${ }^{11}$

Estas relações complexas formam o núcleo de impressões e imagens que de forma recorrente encontra o leitor de Agustina, em contos, romances e comentários sobre o cruzamento de culturas que deu origem ao povo brasileiro, em transformação étnica e capaz de gerar as diferenças e aproximações que delineiam o espaço de um povo formado por tantos povos e tantas nações.

De dentro destas relações complexas, Agustina escreveu o discurso que pronunciou na Academia Brasileira de Letras, representando a caravana de escritores que percorria várias cidades de algumas regiões do Brasil, no ano de 1989.

\footnotetext{
${ }^{9}$ MALDONATO, 2004, p. 106.

${ }^{10}$ MALDONATO, 2004, p. 107.

${ }^{11}$ BESSA-LUÍS, 2007, p. 94-95.
} 
O discurso está datado de 30 de março de 1989 , mas o diário de viagem, Breviário do Brasil, traz a escrita concluída em 28 de junho de 1991. O percurso da caravana tem início no Rio de Janeiro e lá também tem seu encerramento, depois da travessia por Recife, São Luís, Alcântara, Belém, Fortaleza, Manaus, Brasília, Salvador, Ilhéus, Porto Seguro, Belo Horizonte, Ouro Preto, Congonhas do Campo, Mariana, Petrópolis, conferências a outras cidades brasileiras, por ocasião de outras viagens, como Curitiba, João Pessoa, entre outras, sempre relacionadas a heranças portuguesas das artes, da literatura, dos costumes, dos linguajares despertados nas falas das pessoas nas ruas, nas cidadezinhas, nas feiras.

O discurso presta homenagens: à "Casa de glorioso nome", aos mestres do pensamento, às belezas do Rio de Janeiro, "vista do alto é divina e, vista do chão, é humana, a ponto de nos instruir nas contradições", ${ }^{12}$ ao cânone literário brasileiro no século XIX, representado por Machado de Assis e por José de Alencar, aos escritores, poetas e intelectuais como intérpretes das ideias, das contradições, dos sonhos, das frustrações e da "artificialidade" de um povo, isto é, o que ele construiu para defini-lo, depois que as "raízes errantes" se internalizaram e depois levantaram-se como fios em outras direções, como se tivessem cumprido sua finalidade, depois de cinco séculos e se dirigissem a outras paragens, como num desejo de se manterem vivas.

Agustina, ao longo do discurso, através da síntese de comentários, observações e acurada demora nos tipos humanos, nos lugares, faces, odores, desenhos e formas das várias regiões do Brasil, pretende deixar a sua percepção de uma "artificialidade" conquistada, finalmente, ao longo dos séculos que estudiosos, como Gilberto Freire e outros, chamaram de a formação da civilização brasileira, em estudos de Wilson Martins, com História da inteligência brasileira, ou Raizes do Brasil, de Sérgio Buarque de Hollanda. Há uma solenidade na voz que representa seus pares:

Recebidos na Academia, onde se efetua uma sessão de elegia a um de seus membros desaparecidos, somos depois chamados ao convívio com o próprio espírito das Letras Brasileiras, personificado pelo Presidente Austregésilo de Athayde. Diante dum busto de Camões, de bronze escuro, leio a minha comunicação. ${ }^{13}$

${ }^{12}$ BESSA-LUÍS, 1991, p, 89.

${ }^{13}$ BESSA-LUÍS, 1991, p. 89. 
Os destaques da fala de Agustina, a fé e a força ("sal") das palavras reforçam os instrumentos da literatura como forma de animar, de transmitir uma energia ancestral, num momento em que se encontram raízes velhas e raízes de menos de dois séculos; numa Casa a que a escritora intitulou de "glorioso nome". A mulher-escritor, no dizer de Rachel de Queiroz (1910-2003), irmã na sabedoria e na imaginação, faz-se digna pela perseverança no gênio, no compromisso de pôr diante dos leitores a instrução das e nas contradições da vida.

A homenagem de Agustina traz de sua infância e adolescência as leituras que fortaleceram seus dotes de escritora: o domínio na descrição e o poder de refletir sobre o que mostra e o que vemos; através de sua imaginação, pensa a constituição do pensamento, como um feixe de sentidos. Refiro-me aos dois grandes nomes: "Preside a esta Academia o nome de Machado de Assis, escritor que conduziu, com José de Alencar, a minha entrada pela porta grande da literatura brasileira." ${ }_{14}$

Embora outros escritores sejam citados ao longo do Breviário, como Jorge Amado, Clarice Lispector, Raduan Nassar, Agustina destaca a percepção de Machado de Assis como intérprete de seu tempo, de como conjugou, através de "sua proporção de inteligência" para seu lugar, outras terras e outras formas de dizer, em contos e romances, outras maneiras de ler a vida e suas diferenças. Das ligações profundas do homem com suas origens arcanas, de que Agustina provou a obstinação de apreender e compreender os mistérios, para expressá-los em dramas da condição humana, vamos encontrar com José de Alencar um vínculo estranho, quando, nos primeiros livros, Mundo fechado e Contos impopulares, o gosto por uma cultura arcaica, as imagens de leitura, das vozes que the contavam histórias, as figuras que the marcaram a imaginação.

No depoimento de Agustina, assentam-se as raízes românticas que, como lianas, traçarão, ao longo de sua obra, essa inclinação por ouvir a Natureza:

José de Alencar, que eu li à hora do recreio (no Verão, quando as salas de aula ficavam desertas e pelas janelas abertas vinham os gritos de quem corria e jogava à péla), ele foi meu mestre. Digo por quê: porque há nele uma veneração imensa quando fala da natureza e dos homens arrastados no seu poder e acautelados na sua bênção. Ficava,

${ }^{14}$ BESSA-LUÍS, 1991, p. 89. 
da sua leitura, a ideia de que o homem não cede às contrárias tormentas e até as aproveita para deslizar mais depressa nas torrentes enfurecidas. O seu amor resiste à abundância dos terrores que o cercam. Por isso José de Alencar é o mais puro neste negócio de escrever. Outros são mais interessantes e mais astuciosos. Ele não engana ninguém com a sabedoria deste mundo, e por isso parece que não é louco. ${ }^{15}$

O compromisso de interpretar o seu tempo e o voto de não trapacear ou iludir o leitor, mantendo-o ao fiel de uma verdade que se equilibra entre realidade e sonho, Agustina os conjuga em suas linguagens e estilo, o fiel que foi encontrado pelos clássicos e renovado pela transgressão romântica, ou idealista, e, por isso, a escritora inicia sua fala com a imagem eternizada por São Paulo, isto é, a sabedoria do mundo como a base da loucura. Esta imagem junta-se a outras metáforas dos evangelhos, em especial para designar os escritores como aqueles que "em todo o mundo [nós somos como] um rebanho mandado para o matadouro enquanto nos preparam para vencedores". ${ }^{16}$

No fecho do discurso, ficaram inscritos os sentimentos, a emoção, a gravidade de que se revestiu um momento que ali e naquele instante aconteceu e se consumou, a travessia por cidades de diferentes regiões, uma viagem que terminava no lugar em que começara, e Agustina, depois de reforçar as colunas da "Casa ilustre", como símbolo da literatura brasileira, deixa a marca da sensibilidade com que também fascina seus leitores: "O que vimos alimentou em nós o espírito da vida. As nossas obras, durante muito tempo, serão marcadas pelas paisagens e os gostos tão diferentes de Estado para Estado, entre muitos rios e montanhas diferentes. Mas o mais importante, para mim, do que vi, foi esse cálido rosto da bondade [...]. Ele protege a fé no homem. Ele está acima da criação, ou antes dela." ${ }^{17}$

Das errâncias de Agustina por terras brasileiras, confirmando dois nomes importantes de sua travessia pela literatura, essa viagem que começou em 1948 e que tem conhecido tantos temas, situações, pessoas, lugares, do que convencionamos designar como o drama ingente da condição humana, não se negou a compartilhar seus companheiros por caminhos e veredas: livros e escritores, ou seja, temos, tanto em Breviário do Brasil, como nas

\footnotetext{
${ }^{15}$ BESSA-LUÍS, 1991, p. 89.

${ }^{16}$ BESSA-LUÍS, 1991, 90. Grifo nosso.

${ }^{17}$ BESSA-LUÍS, 1991, p. 90.
} 
dezenas de títulos de sua obra, no encerramento da primeira década do século XXI, um cânone compartilhado com seus leitores.

São errâncias que começaram a estender suas nervuras desde os dez anos, quando Agustina entrou para os itinerários e as trilhas do Velho Testamento, e que tiveram prosseguimento no gosto de ler e de escrever ao longo de seus décadas de percurso pelas Letras.

O cânone compartilhado reescreve os conceitos de literatura universal, como uma centralização de escritores clássicos; em outra medida, o nacional, o regional, o marginal se reconfiguram, traduzindo em outras claves a circulação e a recepção de antigos e de novos escritores, promovendo outras visões de influência (Harold Bloom), de apropriação e de transformação de linguagens. $O$ discurso de Agustina na ABL redimensionou as trocas, as mediações entre as literaturas de expressão em língua portuguesa, ao mesmo tempo em que permitiu que os escritores visitantes, ao percorrerem, ao errarem, na dispersão de tantos lugares e culturas no Brasil, revisassem sua imagem lançada contra tão diferentes feições e performances na arte de escrever. Examinadas pela ótica do descentramento do sistema literário, a partir da queda das fronteiras, e de outra interpretação para a relação Brasil - Europa - Brasil, categorias como tradição, origem e cânone são desmistificadas sob o signo das trocas, desapropriações, reapropriações, redimensionamento de temas afins, pelo impacto das revisões românticas, no sentido de transgressoras, dos modernismos de fins do século XIX e intensamente retomados pelas gerações de poetas e escritores, ao longo do século XX. Tais categorias reescrevem as relações da literatura com os elementos da comunicação, fazendo do discurso literário um campo aberto de lutas e disputas, dentro do qual, os cânones, as origens e as tradições se reorganizam a partir das forças que entre si agem dentro do campo das linguagens. ${ }^{18}$

As relações em que se sustentavam os polos centro x periferia x margens são modificadas em função da errância comparatista que desde há muito lançou as bases da desconfiança, da suspeita, da ironia, proporcionando uma saudável revisão conceitual. A percepção errante para o cânone, dentro da feição comparatista das linguagens da literatura, fez-se a marca da segunda metade do século XX, desde os anos 1940, com um novo espírito das letras, manifestado não apenas através da estilização arrojada nas formas poéticas e narrativas, mas sobretudo na consciência paulatina de uma redescoberta da humanidade do homem.

\footnotetext{
${ }^{18}$ JOBIM, 1992.
} 
Procurando no Brasil as pistas do mistério da travessia que começou no século XVI, Agustina também investiga, desde a fala pura em bom sotaque brasileiro, a verdade que desenha a diferença do Outro, fazendo-o de mito necessário para alimentar o fascínio dos mitos. No dizer de Tania Carvalhal,

o comparatismo contrasta os textos e as personagens em uma reflexão que permite a releitura dos mitos e das lendas, dos gêneros e da ideia de romance até o ponto de se interrogar sobre o que mudou no mundo e nas relações humanas para que um cavaleiro passe de uma presença que se impõe a sua própria invisibilidade. ${ }^{19}$

Tania Carvalhal usa a imagem da errância a partir do cavaleiro de Cervantes, "a busca infatigável do sonho e a luta pela sua realização", ${ }^{20}$ característica de Dom Quixote, reescrita quatro séculos depois no personagem de Italo Calvino, no cavaleiro que não tinha figura, ou $O$ cavaleiro inexistente, o qual evoca, na semelhança do tema e do mito, o Riobaldo de Guimarães Rosa.

Num momento em que eram preparadas homenagens pelos noventa anos de Agustina (nascida em 15 de outubro de 1922), que fez de seu estilo inconfundível a marca de sua paixão pela escrita poética e, ao mesmo tempo, quando livros perguntam: Literatura, para quê? (Antoine Compagnon, 2009), A literatura em perigo (Tzvetan Todorov, 2007), para Tania Carvalhal, "Sob a égide do Cavaleiro errante, em suas múltiplas variações, a literatura comparada vive a aventura dos tempos e enfrenta, na formulação de perguntas, a sua permanente validação." ${ }_{21}$

A lição de comparatismo, de congraçamento, em que as diferenças realçaram as descobertas de outros tempos, de outros motivos, de outras razões para que o sistema literário reconfigure seus elementos como um processo em andamento de trocas, de ganhos e de dispersões, proferida por Agustina para a sessão na Academia Brasileira de Letras ganhou em definitivo, para a memória viva da língua portuguesa, um momento novo, em que se fortaleceram os laços, se reconfiguraram as raízes, se reenergizaram as fontes dos mitos, muitos deles comuns a muitos povos, provando a vitalidade do fazer literário e de seu papel na re-humanização

\footnotetext{
${ }^{19}$ CARVALHAL, 2006, p. 17.

${ }^{20}$ CARVALHAL, 2006, p. 16.

${ }^{21}$ CARVALHAL, 2006, p. 17.
} 
do homem, dentro da mesma compreensão do comparatismo atual, errância e dispersão de linguagens.

Entre as lembranças de viajantes que voltavam a Portugal depois da "experiência Brasil", Agustina retém aquelas que seriam, depois, transformadas, pela ação da linguagem simbólica e pelo modo como passariam aos enredos de contos e romances, ou ainda, no estilo casual da crônica, espaço de afirmação de muitas das protonarrativas que ganharão os domínios romanescos, destaca-se a imagem de Maria Bonita, o par de Lampião. Se tratarmos o fato conhecido com os acréscimos da lenda, poderíamos relacioná-la entre os arquétipos literários do maravilhoso, ou seja, pela tópica do "rapto da mulher-heroína". ${ }^{22}$

Antes de tratar a memória popular como tópica mágica, ou seja, através do impossível de uma mulher simples, pobre, esposa e mãe, com vida estabelecida em pequeno povoado nordestino, romper com o prosaico do cotidiano e entrar para a ilusão de arrostar as aventuras de um bando fora-da-lei, lembramos que entre a noite e o amanhecer, os nomes saltam para o mito, para o epos heroico, invadem a lenda e se tornam de tal magnitude que não cabem na exiguidade do dia a dia.

O conteúdo arquetípico da imagem da mulher transgressora incomoda a ordem das coisas e Maria Bonita sai da história da vida comum do nordeste brasileiro, ganha ares de personagem de peça de teatro, com Rachel de Queiroz e assume o centro do enredo e do palco, para tornar-se a figura principal de uma trajetória curta e acidentada, não propriamente por rapto, pois ela saiu de casa por seu livre querer, mas por uma questão de cumprimento de destino. Não seria outro o seu destino, que o de fazer-se pelos sertões e caatingas, grutas e esconderijos, para realizar a verdade de sua vida: "Menino, diga lá ao seu capitão que, se ele quiser vir me buscar, eu sigo no bando e ganho o mundo com eles. Me chamo Maria Déa e sou mulher do sapateiro." ${ }^{23}$

Recebido o recado, foi pensada, mas pronta a resposta em ação: "Então a senhora era capaz de ganhar o mundo com a gente, bastava só Lampião querer?" [...] "É" [...] "Pois está aqui Lampião. Vim buscar a senhora." 24

Da vida para a lenda, no cumprimento dos costumes daqueles que fizeram seus próprios códigos de conduta, a personagem, do imaginário

\footnotetext{
${ }^{22}$ MELETINSKI, 1998, p. 157.

${ }^{23}$ QUEIROZ, 2005, p. 18.

${ }^{24}$ QUEIROZ, 2005, p. 23.
} 
sertanejo, faz-se símbolo de determinação e rebeldia, conquistando também outras culturas igualmente constituídas das muitas das mais antigas representações ibéricas, como bens que cruzaram os mares das Américas e entre novas figurações se juntaram para a teia que recomeça toda as vezes que seus encantamentos são evocados.

Agustina, em crônica nomeada "Maria Bonita", de fevereiro de 1992, para o Jornal de Letras, Artes e Ideias, anuncia que vai "falar de uma coisa simples":

Mais do que simples: rasteira mesmo e confidencial. Não sei como me lembrou, mas a figura da Maria Bonita que foi companheira do célebre bandido do Agreste brasileiro chamado Lampião, apareceu-me hoje com toda a nitidez, no espelho à luz da madrugada. Eu sempre achei que o Lampião, ou Virgulino Ferreira, e Maria Bonita assentavam de alma e coração no duo Bonnie e Clyde. A mesma fantasia heroica do delinquente por fracasso e a quem a sociedade de grandes espaços convida ao crime improvisado. Não se trata, inicialmente, de um bando organizado, como o de Al Capone, mas de um duelo rural entre o desclassificado e a lei que pouco tem de jurídico. ${ }^{25}$

A leitura do mito nordestino, já consagrado pela encenação teatral de Rachel de Queiroz e caracterizada in media res, quando a vida lança os viventes no desatino do impulso, da forma como Agustina o surpreende, "no espelho, à luz da madrugada", corre ao pé do modo como acontecem as imagens obsedantes - imagens perseguidoras, em busca de uma expressão, a fim de que sejam liberadas e possam encontrar aqueles que as aguardam, na ansiedade dos que, pelos símbolos, também cruzam a vau da ficção.

Não deixa de ser curioso que a percepção de Agustina para o mito de Maria Bonita se dê por dois indícios, aqueles que participam do espaço intervalar entre realidade e ficção: o espelho, que absolutamente não reproduz o objeto observado, mas que apresenta aos olhos que fixam a sua superfície uma imagem-motivada; e o outro, "luz da madrugada", momento difuso, em que a noite começa a dissipar; no entanto, ainda não há claridade suficiente para que o contorno dos objetos seja delineado com nitidez. Os dois indícios esfumam a realidade histórica, para que a linguagem poética assente em grande medida os signos da fantasia, na composição da lenda:

${ }^{25}$ BESSA-LUÍS, 1992, p. 7. 
O Lampião deu em cismar com tanta boniteza e a guardarlhe respeito, como às santas dos altares. Não era uma rapariga que se lhe oferecia, mas uma barbeira com enxotamoscas na mão e que sabia de cor os versos de cordel, que falavam dele, capitão Virgulino Ferreira, por alcunha "o pé ligeiro". Dançava bem e usava óculos fumados. É um corsário do mato e não lhe falta mesmo a perna manca e a ferocidade profissional. Não matava por prazer, mas para manter a fama que vive do susto e da sede de invenção. ${ }^{26}$

Por arte da memória, a escritora portuguesa toma posse de um nome-lenda e o faz motivo seu, com ele afinando-se e lhe dedica, em Breviário do Brasil, ${ }^{27}$ demoradas considerações intercaladas de digressões psicológicas, éticas, morais, religiosas e estéticas, contribuindo para emoldurar a história de Lampião e Maria Bonita em duas dimensões: o mito como representação do coletivo, com os paradoxos que lhe cabem, a partir da leitura de Lampião na Bahia, livro comprado em Petrópolis:

A história de Lampião nunca foi contada como verdadeira ortodoxia do celerado. [...] Atribuíam-lhe favores dos deuses da selva, que não são propriamente deuses de paz. Ele próprio se julgava “corpo fechado", isto é, invulnerável às balas. [...] Lampião era dotado do dom raríssimo da atenção. Nele reside a faculdade de amar e de odiar. [...] Distribuía dinheiro e favores com esse prazer arrepiante que faz de cada inocente um parceiro no crime. Quando se apaixonou por Maria Bonita, ou Maria de Déia (sic), essa qualidade da atenção fez-se presente no nervo do amor mais autêntico. É quase comovente o encontro com o mensageiro de Maria Bonita que lhe transmite o recado da moça, mal casada e sonhadora duma paixão perigosa. Lampião mostra-se relutante, sabe que uma quadrilha com mulheres está sujeita a limitações. ${ }^{28}$

Os impulsos e devaneios da paixão desfazem a face coletiva do mito, de famigerado facínora, adicionando-lhe as notações de simples humanidade - os traços da hesitação e da consciência dos riscos.

\footnotetext{
${ }^{26}$ BESSA-LUÍS, 1992, p. 7.

${ }^{27}$ BESSA-LUÍS, 1991, p. 48-53.

${ }^{28}$ BESSA-LUÍS, 1991, p. 48.
} 
Desfazem-se os traços golpeados na figura do mito. De leitura curiosa a manifestação de interesse obsessivo, o mito-lenda invade o pensamento de Agustina e ocupa outras páginas, como as que encontramos em Breviário do Brasil, atraindo para a escrita "uma singularidade própria do brasileiro: o disfarce da sua natureza trágica. Disfarce que, não raro, toma o aspecto de alegria tumultuosa e do crime mais violento." 29

Neste passo, por incisiva insistência, o mito se pessoaliza, internalizando-se entre os motivos preferidos, integrando-se aos tipos reclamados pela escrita híbrida entre História - mito - ficção.

Este é o terreno em que se assentam aquelas imagens "do mundo interior do escritor", ${ }^{30}$ organizando-se como elemento integralizador do imaginário, alcançando suas categorias, fazendo-se de "figura", ${ }^{31}$ entre os "mitos pessoais". Já não é possível desentranhar Maria Bonita, Maria Déa, Maria de Déia de entre as teias com que se movem os fios narrativos de Agustina.

Os mitos pessoais transitam pelos meandros labirínticos do mundo da ficção de Agustina, percorrendo em suas humanas andanças, por diferentes tipos de escrita e de louvações, sem esconder as faces escuras e sombrias guardadas nos movimentos do claro-escuro, artifícios usados pela escritora para fazer de um mundo de verdades tiradas dos nossos, nem melhores, nem piores, verossimilmente recriadas de nossas várias e cambiantes aparências.

As errâncias dos mitos garantem-lhes vida longa e fecunda: os mesmos e diferentes assemelham-se em sua porosa natureza de cambiantes performances, diferem entre si, na vontade de encarnar singulares traços que possam individualizá-los, através de nomes-chaves com que são convocados a reviver as tramas que urdiram na verdade efêmera e de vocação imortal, inteiramente dependentes das necessidades humanas de representar, em significantes de emoção e de instinto, os fugidios traços que brilham enquanto os raios em rotação incansável tocam arestas de sua forma sisífica. $\mathrm{O}$ toque do tempo, no cruzamento dos instantes de criação, reaviva os traços, por átimos de momento, das representações arcaicas, aquelas que permitem ao homem reconhecer-se no sublime e no desenho esgarçado que lhe deforma os ângulos expostos ao ácido que os faz tomar novos e outros contornos.

\footnotetext{
${ }^{29}$ BESSA-LUÍS, 1991, p. 51.

${ }^{30}$ TROUSSON, 1988, p. 15.

${ }^{31}$ AUERBACH, 1997.
} 


\section{Referências}

AUERBACH, Erich. Dante: poeta do mundo secular. Tradução de Raul de Sá Barbosa. Rio de Janeiro: Topbooks, 1997.

BARTHES, Roland. O que é a crítica. In: . Ensaios críticos. Tradução de António Masano e Isabel Pascoal. Edições 70: Lisboa, 2009. p. 157.

BESSA-LUÍS, Agustina. O Livro de Agustina Bessa-Luís. Lisboa: Guerra e Paz, 2007.

BESSA-LUÍS, Agustina. O princípio da incerteza. Lisboa: Guimarães, 2002. v. 3: A alma dos ricos.

BESSA-LUÍS, Agustina. Breviário do Brasil. Ed. bilíngue. Lisboa: Asa, 1991.

BESSA-LUÍS, Agustina. Contemplação carinhosa da angústia. Lisboa: Guimarães, 2000.

BESSA-LUÍS, Agustina. Maria Bonita. Jornal de Letras, Artes e Ideias, Lisboa, ano XI, n. 500, p. 4-10, fev. 1992.

BESSA-LUÍS, Agustina. Mundo fechado. Lisboa: Guimarães, 1948.

BLOOM, Harold. Angústia da influência. Tradução de Marcos Santarrita. Rio de Janeiro: Imago, 2002.

BOURDIEU, Pierre. As regras da arte. Tradução de Maria Lucia Machado. São Paulo: Companhia das Letras, 1996.

CARVALHAL, Tania. Sob a égide do cavaleiro errante. Revista Brasileira de Literatura Comparada, Rio de Janeiro, v. 8, p. 11-18, jul. 2006.

COMPAGNON, Antoine. Literatura, para quê? Tradução de Laura Taddei Brandini. Belo Horizonte: Editora UFMG, 2009.

JOBIM, José Luis. História da literatura. In: crítica. Rio de Janeiro: Imago, 1992. p. 127-149. (Org.). Palavras da

LOPES, Óscar apud MACHADO, Álvaro Manuel. A vida e a obra de Agustina Bessa-Luís. Lisboa: Arcádia, 1979. p. 16.

MACHADO, Álvaro Manuel. A vida e a obra de Agustina Bessa-Luís. Lisboa: Arcádia, 1979.

MAINGUENEAU, Dominique. O contexto da obra literária. Tradução de Marina Appenzeller. São Paulo: Martins Fontes, 1995. 
MALDONATO, Mauro. Raízes errantes. Tradução de Roberta Barni. São Paulo: SESC São Paulo / Editora 34, 2004.

MELETINSKI, Eleazar M. Os arquétipos literários. Tradução de Aurora Fornoni Bernardini, Homero Freitas de Andrade e Arlete Cavaliere. São Paulo: Ateliê Editorial, 1998.

MORIN, Edgar. Introdução ao pensamento complexo. Tradução de Eliane Lisboa. Porto Alegre: Sulina, 2006.

QUEIROZ, Rachel de. Lampião. A beata Maria do Egito. 5. ed. Rio de Janeiro: José Olympio, 2005.

SARTRE, Jean-Paul. O que é a literatura. Tradução de Carlos Felipe Moisés. São Paulo: Ática, 1994.

TODOROV, Tzvetan. A literatura em perigo. Tradução de Caio Meira. Rio de Janeiro: DIFEL, 2009.

TROUSSON, Raymond. Temas e mitos. Questões de método. Tradução de Teresa Castro Rodrigues. Lisboa: Livros Horizonte, 1988. 